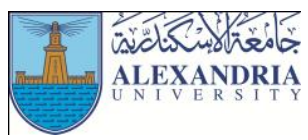

\author{
Journal of Applied Sports Science \\ September 2016, Volume 6, No. 3 \\ www.jass.alexu.edu.eg
}

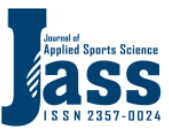

\title{
The Ministry of Youth and Sports Contributions in Achieving Sustainable Development of the Arab Republic of Egypt
}

\author{
Reham Amin Hamzah ${ }^{1}$ \\ ${ }^{1}$ Lecturer, Department of Sport Management, Faculty of Physical Educatiobn for Girls, Alexandia University, Egypt
}

\begin{abstract}
The research aims to identify the contributions of each of the ministries of youth and sports in the achievement of sustainable development in the Arab Republic of Egypt, through the environmental, economic and social dimensions, and the researcher has used the descriptive survey of relevance that comply the nature of the research, the research was applied on a sample from the ministries of youth and sports, and departments of Youth and Sports in different governorates, the researcher used the form questionnaire and interview as tools for collecting data and information were used the occasion to such data and information statistical methods. The research has come to the importance of strengthening existing partnerships between the various sports organizations and the civil society and governments and to establish new partnerships to help take actions sports programs in order to achieve sustainable development in the Arab Republic of Egypt's private sector.
\end{abstract}

\section{Research problem and its importance}

$\mathrm{T}$ he first principle of the Declaration of the United Nations Conference on environment and development in Rio de Janeiro, Brazil in 1992 of human beings at the Centre of concerns for sustainable development, there is no denying the role of sport in achieving these goals.

Defined by both of Khaled Mustafa Kassem (2007), Ammar Amari (2008), Talaat Moustafa Alsorougy (2009), Salah Abbas (2010), sustainable development development process of ongoing comprehensive economic, social, cultural and political aims to achieve progress in the lives of individuals and their welfare through the contribution of all members of society on the base of equitable distribution of revenues (16:19) (5:4) $(30: 17)(28: 212)$

Identifies all of the Osman Mohammed Ghneim, Magda Abu Zant (2010), Asia kasimi (2012) of sustainable development properties as follow:

1- Sustainable development is a shared responsibility and a comprehensive development in all sectors of the State

2- For sustainable development, environmental, social and economic dimensions are interrelated and overlapping with each other in an interactive window exactly and organization and rationalization. (27:30, 31), (6:7), (39)
Sheikh Mohammed Saleh AlSheikh identifies (2002) dimensions of sustainable development to include three overlapping dimensions and tangled in an interactive window exactly regulation and rationalization, these dimensions are as follows: (21:93)

Environmental dimension: the need to maintain he environment, guaranteeing the nature intact and ensure production of renewable resources with non-renewable resource depletion. (23:135)

Health environment: necessary to exercise, they pay a lot of athletes and inspire them meanwhile. (31:2)

The economic dimension: continuity and sustainability means that generate high income can reinvest part of it even allow for replacement, renovation and maintenance of resources. (27:39)

Sports in general are an integral part of economic life, so must highlight the sporting institutions to see how those institutions seeking to develop their resources. (41), (42)

Social dimension: focuses on the essence of human development through attention to social justice and fighting poverty and providing social services. (23:136), $(31: 3)$

The success of sustainable development must link these hubs and integrated view of the close link between the environment and the economy and social security. (40) 
The researcher has adopted these dimensions of sustainable development as the basis of the questionnaire list described in the research procedures

Hassan Ahmed Shafi'i (2012) clarifies some difficulties facing the sustainable development of sports institutions as follows:

- Shrinking share stadiums spaces of individual sports.

- Total reliance on Government support and a few nongovernmental funding sources.

- The absence of the role of sports media education on the role and significance of sport for society.

- Central Government control in sports organizations. $(15: 22,23)$

The researcher has the problem of searching from "Egypt's Vision 2030," announced Chairman abdulfattah Sisi, asserting the State's intention to achieve comprehensive development in various fields including puts Egypt in 30 countries around the world by 2030. (36)

It also recommends that the United Nations General Assembly of the need to develop indicators and benchmarks to assist Governments in enhancing the status of sport in the overall development strategies. (38)

Through the pilot study carried out by the researcher (annex 1) and is applied to a sample (15) to learn about the role of the Ministry of youth and sports in achieving sustainable development within the Arab Republic of Egypt.

It confirmed that the Ministry of youth and sports does not give enough effort as the desired shape in a balanced environment, the lack of coordination and cooperation between the Ministry of youth and sports and various sports institutions to activate its role in increasing economic returns to the State sports organizations not contributing to reduce crime and violence through dialogue and negotiation which affect Community recklessness.

Through the researcher informed on many previous studies such as the results of a study of Badr Muhammad Alwan (2012) (7) study, Najat Abdullah Wali (2012) (25) study Hassan Ahmed Shafi'i, Mustafa Kamil alzenkloni (2009) (14) study Omar Nasrallah synths, Rehab Amin (2009) (26) study Hmimh Ibrahim hashish, Samah Ahmed (2010) (12) mtanious study entitled, Adnan Ghanim (2009) (22) that there is a correlation between the effectiveness of internal control and sustainable development in government circles inside her. If environmental constraints affect the sustainable development of sports institutions to measure the environmetal performance of the sports institution achieves the protection and preservation of the environment and its components, and that "OECD" (2012) (34) on the importance of integrating environmental objectives into economic policies.

\section{Research aims}

Identify the contributions of the Ministry of youth and sports in achieving sustainable development in Arab Republic of Egypt through the following dimensions

- Environmental dimensions of Ministry of youth and sports to achieve sustainable development

- Economic dimensions of Ministry of youth and sports to achieve sustainable development

- The social dimensions of the Ministry of youth and sports to achieve sustainable development.

\section{Research procedures}

\section{Research method}

Using descriptive survey of manageable nature of research.

Research Sample: is selected in the categories "Ministry of youth and sports, youth and sports directorates in various provinces, with the total sample (232) of the total sample of search number (258)

\section{Data collection tools}

The researcher designed a questionnaire to collect data

\section{Questionnaire scientific transaction:}

First: Validity: A- Coefficient of internal consistency of questionnaire 
Table (1)

the consistency factor correlation degree phrase total dimension $n=15$

\begin{tabular}{|c|c|c|c|c|c|c|c|}
\hline $\begin{array}{l}\text { Constency } \\
\text { Coefficient }\end{array}$ & Phrase N & $\begin{array}{l}\text { Constency } \\
\text { Coefficien }\end{array}$ & Phrase N & $\begin{array}{l}\text { Constency } \\
\text { Coefficient }\end{array}$ & Phrase N & $\begin{array}{l}\text { Constency } \\
\text { Coefficient }\end{array}$ & Phrase N \\
\hline$* * 0.702$ & $4 / 30$ & $* * 0.648$ & 27 & $* * 0.712$ & 14 & \multicolumn{2}{|c|}{ he first axis: environmental dimensions } \\
\hline$* * 0.712$ & $5 / 30$ & \multicolumn{2}{|c|}{ Axis III: social dimensions } & \multicolumn{2}{|c|}{$\begin{array}{l}\text { Axis II: economic } \\
\text { dimensions }\end{array}$} & $* * 0.707$ & 1 \\
\hline & 31 & & 28 & $* * 0.671$ & 15 & $* * 0.663$ & 2 \\
\hline$* * 0.717$ & $1 / 31$ & $* * 0.699$ & $1 / 28$ & $* * 0.721$ & 16 & $* * 0.644$ & $\begin{array}{l}\text { Axis III: social } \\
\text { dimensions }\end{array}$ \\
\hline$* * 0.648$ & $2 / 31$ & $* * 0.688$ & $2 / 28$ & $* * 0.658$ & 17 & $* 0.597$ & 4 \\
\hline$* * 0.721$ & $3 / 31$ & $* * 0.661$ & $3 / 28$ & $* * 0.712$ & 18 & & 5 \\
\hline$* * 0.711$ & $4 / 31$ & $* * 0.745$ & $4 / 28$ & $* * 0.737$ & 19 & $* 0.615$ & $1 / 5$ \\
\hline$* * 0.732$ & $5 / 31$ & $* * 0.727$ & $5 / 28$ & $* * 0.714$ & 20 & $* * 0.771$ & $2 / 5$ \\
\hline$* * 0.659$ & 32 & $* * 0.802$ & $6 / 28$ & $* * 0.723$ & 21 & $* * 0.801$ & $3 / 5$ \\
\hline$* * 0.677$ & 33 & & 29 & & 22 & $* * 0.672$ & 6 \\
\hline$* * 0.800$ & 34 & $* * 0.768$ & $1 / 29$ & $* * 0.718$ & $1 / 22$ & $* * 0.695$ & 7 \\
\hline$* * 0.674$ & 35 & $* * 0.662$ & $2 / 29$ & $* * 0.645$ & $2 / 22$ & $* * 0.789$ & 8 \\
\hline$* * 0.667$ & 36 & $* * 0.722$ & $3 / 29$ & $* * 0.659$ & $3 / 22$ & $* * 0.650$ & 9 \\
\hline$* * 0.720$ & 37 & & 30 & $* 0.581$ & 23 & $* * 0.731$ & 10 \\
\hline$* * 0.659$ & 38 & $* * 0.756$ & $1 / 30$ & $* * 0.653$ & 24 & $* * 0.675$ & 11 \\
\hline \multirow[t]{2}{*}{$* * 0.714$} & 39 & $* * 0.671$ & $2 / 30$ & $* * 0.728$ & 25 & $* * 0.658$ & 12 \\
\hline & & $* * 0.680$ & $3 / 30$ & $* 0.589$ & 26 & $* * 0.730$ & 13 \\
\hline
\end{tabular}

*Significant with $0,05=0,497$

$* *$ Significant with $0,01=0,623$

Table (2)

internal consistency coefficient correlation dimension degree total axis $\mathrm{n}=15$

\begin{tabular}{|c|c|}
\hline Internal consistency coefficient & Axes. \\
\hline$* * 0.709$ & Axis I: environmental dimensions by Ministry of youth and sports to achieve sustainable developmen \\
\hline$* * 0.722$ & Axis II: economic dimensions by Ministry of youth and sports to achieve sustainable development. \\
\hline$* * 0.716$ & Axis III: social dimensions by Ministry of youth and sports to achieve sustainable development \\
\hline
\end{tabular}

**Significant with $0,01=0,623$

* Significant with $0,05=0,497$

\section{Second: The stability: Alphakronbakh stability}

Table (3)

alpha kronbak coefficient for phrases and themes of the questionnaire $\mathrm{N}-15$

\begin{tabular}{|c|c|c|}
\hline \multicolumn{2}{|c|}{ alpha kronbak coefficient } & \multirow[b]{2}{*}{ Axes. } \\
\hline $\begin{array}{l}\text { For questionnaire as } \\
\text { all }\end{array}$ & For Axes. & \\
\hline \multirow{3}{*}{0.812} & 0.724 & $\begin{array}{l}\text { The first axis: environmental dimensions by Ministry of youth and sports to achieve } \\
\text { sustainable developmen }\end{array}$ \\
\hline & 0.769 & $\begin{array}{l}\text { Axis II: economic dimensions by Ministry of youth and sports to achieve sustainable } \\
\text { development. }\end{array}$ \\
\hline & 0.736 & $\begin{array}{c}\text { Axis III: social dimensions by Ministry of youth and sports to achieve sustainable } \\
\text { development }\end{array}$ \\
\hline
\end{tabular}

Illustrated by table (3) for the Alphakronbakh coefficient

for phrases and themes of the questionnaire high values

values greater than 0 .

\section{Statistical transactions:}


Appropriated transaction was utilized for the research natur

\section{Discussion: Results}

Table (4)

approval of the first axis phrases: environmental dimensions $n=232$

\begin{tabular}{|c|c|c|c|c|c|c|c|c|c|c|c|c|c|c|c|}
\hline \multicolumn{2}{|c|}{$\begin{array}{l}\text { Research group at all } \\
n=232\end{array}$} & \multirow{2}{*}{$\begin{array}{l}\text { q2 for the } \\
\text { two classes }\end{array}$} & \multicolumn{6}{|c|}{ Second class : Youth directorates $n=219$} & \multicolumn{6}{|c|}{ First class:Ministry of YOUTH:N=19 } & \multirow{2}{*}{$\begin{array}{c}\text { Phrase } \\
n\end{array}$} \\
\hline arrangement & $\begin{array}{c}\text { Approval } \\
\text { rate }\end{array}$ & & $\begin{array}{c}\text { Approval } \\
\text { rate }\end{array}$ & mean & $\mathrm{q}^{2}$ & no & fairly & Yes & $\begin{array}{c}\text { Approval } \\
\text { rate }\end{array}$ & mean & $q^{2}$ & no & fairlyl & Yes & \\
\hline & 55.17 & 0.64 & 54.46 & 1.09 & *169.89 & 17 & 160 & 36 & 63.16 & 1.26 & 5.16 & 2 & 10 & 7 & 1 \\
\hline & 42.67 & 1.94 & 41.55 & 0.83 & $* 9.13$ & 89 & 71 & 53 & 55.26 & 1.11 & 0.74 & 6 & 5 & 8 & 2 \\
\hline & 62.93 & 0.27 & 62.44 & 1.25 & ${ }^{*} 79.13$ & 18 & 124 & 71 & 68.42 & 1.37 & 4.53 & 2 & 8 & 9 & 3 \\
\hline & 30.82 & $* 4.24$ & 29.34 & 0.59 & $* 61.38$ & 106 & 89 & 18 & 47.37 & 0.95 & 0.11 & 7 & 6 & 6 & 4 \\
\hline & & & & & & & & & & & & & & & 5 \\
\hline & 77.16 & 0.02 & 77.00 & 1.54 & $* 97.89$ & 6 & 86 & 121 & 78.95 & 1.58 & $* 9.58$ & 1 & 6 & 12 & $1 / 5$ \\
\hline & 71.34 & 0.05 & 71.13 & 1.42 & $* 63.89$ & 17 & 89 & 107 & 73.68 & 1.47 & $* 6.42$ & 2 & 6 & 11 & $2 / 5$ \\
\hline & 67.24 & 0.12 & 66.90 & 1.34 & *36.51 & 35 & 71 & 107 & 71.05 & 1.42 & 5.47 & 3 & 5 & 11 & $3 / 5$ \\
\hline & 71.34 & 0.05 & 71.13 & 1.42 & $* 63.89$ & 17 & 89 & 107 & 73.68 & 1.47 & $* 6.42$ & 2 & 6 & 11 & 6 \\
\hline & 46.77 & 1.42 & 45.77 & 0.92 & $* 9.13$ & 89 & 53 & 71 & 57.89 & 1.16 & 2.00 & 6 & 4 & 9 & 7 \\
\hline & 51.08 & 0.96 & 50.23 & 1.00 & $* 241.89$ & 17 & 178 & 18 & 60.53 & 1.21 & $* 6.42$ & 2 & 11 & 6 & 8 \\
\hline & 63.15 & 0.25 & 62.68 & 1.25 & $* 27.38$ & 35 & 89 & 89 & 68.42 & 1.37 & 3.89 & 3 & 6 & 10 & 9 \\
\hline & 71.34 & 0.05 & 71.13 & 1.42 & $* 63.89$ & 17 & 89 & 107 & 73.68 & 1.47 & $* 6.42$ & 2 & 6 & 11 & 10 \\
\hline & 54.74 & 0.72 & 53.99 & 1.08 & $* 61.38$ & 36 & 124 & 53 & 63.16 & 1.26 & 2.63 & 3 & 8 & 8 & 11 \\
\hline & 30.82 & $* 4.24$ & 29.34 & 0.59 & $* 61.38$ & 106 & 89 & 18 & 47.37 & 0.95 & 0.11 & 7 & 6 & 6 & 12 \\
\hline & 74.57 & 0.02 & 74.41 & 1.49 & $* 97.80$ & 3 & 103 & 107 & 76.32 & 1.53 & $* 8.00$ & 1 & 7 & 11 & 13 \\
\hline & 46.98 & 1.36 & 46.01 & 0.92 & $* 61.38$ & 53 & 124 & 36 & 57.89 & 1.16 & 1.37 & 4 & 8 & 7 & 14 \\
\hline
\end{tabular}

q2 significant among responses with $0,05=5,99$

Illustrated by table (4) search sample consensus about terms of numbers (3:1) with low approval percentage value ranged between (42.67:62.93\%) Not sought County youth and sports to achieve the environmental dimension of sustainable development through the inclusion of the human right to a balanced and sustainable development environment, through a culture of conservation and natural resources for future generations, as well as legislation and regulations specify the maximum concentration levels for environmental contaminants are allowed

This is confirmed by both of Hayward Hayward (2005), Monica Freeman Monika Freyman (2012) (33): the right of all individuals to be free from pollution and other activities which adversely affect human life. (35:30)

Abdul Aziz mukhaimar Abdul Hadi refers (2007): the Egyptian Constitution should contain explicit provision on the right to an environment free from pollution. (1:8)

The researcher considers the importance of linking the promotion of sports movement to preserve the environment, considering that sport and the environment are two sides of the same coin significant between the two classes $=3,84$

While respondents had divergent views about the phrases numbers $(4,12)$ worth squared $(4,24 *)$ as percentage of the approval of the Ministry of youth and sports (47.37\%) The proportion of youth and sports modiriat approval (29.349\%) Not encourage all stakeholders from Governments and non-governmental organizations to activate the tripartite system and not to expand the use of clean and renewable energy sources in the sports facilities

Study results indicate Mohammed Abbas Badawi (2011) (25th), international forum of sports (2012): the importance of tourism and environmental system activation during practice sportsmanship. (11:5) (19:213)

While there was consensus among respondents about phrase number $(5,6)$ by consent ranged between $(67.24: 77.16 \%)$ On the environmental dimension in development plans at the Olympic or regional courses, when choosing the location of clubs and youth centres,

This is consistent with the results of a Phalistenian sport and Environment Commission (2012) (37), to preserve the environment in States hosting the courses longer in key priorities when planning to establish these tournaments.(37) 
Green sports green coalition emphasizes sports alliance (2015) (43): the importance of applying better environmental governance within the sport.
Adds Mohammed Abu Kassim Mohamed (2005) that the availability of an efficient environmental management leading to ensure continued development (20:24)

Table (5)

percentage of approval on second terms: economic dimensions $(n=232)$

\begin{tabular}{|c|c|c|c|c|c|c|c|c|c|c|c|c|c|c|c|}
\hline \multicolumn{2}{|c|}{$\begin{array}{l}\text { Research group at all } \\
\mathrm{n}=232\end{array}$} & \multirow{2}{*}{$\begin{array}{l}\text { q2for the } \\
\text { two classes }\end{array}$} & \multicolumn{6}{|c|}{ Second class :Youth directorates $n=213$} & \multicolumn{6}{|c|}{ First class:Ministry of YOUTH:N=19 } & \multirow{2}{*}{$\begin{array}{c}\text { Phrase } \\
\mathrm{n}\end{array}$} \\
\hline arrangement & $\begin{array}{c}\text { Approval } \\
\text { rate }\end{array}$ & & $\begin{array}{l}\text { Approval } \\
\text { rate }\end{array}$ & mean & $\mathbf{q}^{2}$ & No & fairly & Yes & $\begin{array}{l}\text { Approval } \\
\text { rate }\end{array}$ & mean & $q^{2}$ & NO & fairly & Yes & \\
\hline & 39.01 & 2.43 & 37.79 & 0.76 & $* 25.89$ & 88 & 89 & 36 & 52.63 & 1.05 & 0.11 & 6 & 6 & 7 & 15 \\
\hline & 62.93 & 0.27 & 62.44 & 1.25 & $* 79.13$ & 18 & 124 & 71 & 68.42 & 1.37 & 4.53 & 2 & 8 & 9 & 16 \\
\hline & 46.98 & 1.36 & 46.01 & 0.92 & $* 61.38$ & 53 & 124 & 36 & 57.89 & 1.16 & 1.37 & 4 & 8 & 7 & 17 \\
\hline & 34.91 & 3.23 & 33.57 & 0.67 & $* 61.89$ & 88 & 107 & 18 & 50.00 & 1.00 & 0.11 & 6 & 7 & 6 & 18 \\
\hline & 34.70 & 2.35 & 33.57 & 0.67 & $* 61.89$ & 88 & 107 & 18 & 47.37 & 0.95 & 1.37 & 8 & 4 & 7 & 19 \\
\hline & 31.25 & $* 6.62$ & 29.34 & 0.59 & $* 61.38$ & 124 & 53 & 36 & 52.63 & 1.05 & 3.26 & 4 & 10 & 5 & 20 \\
\hline & 40.09 & $* 8.99$ & 37.56 & 0.75 & ${ }^{*} 187.13$ & 53 & 160 & 0 & 68.42 & 1.37 & $* 7.05$ & 1 & 10 & 8 & 21 \\
\hline & & & & & & & & & & & & & & & 22 \\
\hline & 71.34 & 0.05 & 71.13 & 1.42 & $* 63.89$ & 17 & 89 & 107 & 73.68 & 1.47 & $* 6.42$ & 2 & 6 & 11 & $1 / 22$ \\
\hline & 73.28 & 0.07 & 73.00 & 1.46 & *92.06 & 5 & 105 & 103 & 76.32 & 1.53 & *8.00 & 1 & 7 & 11 & $2 / 22$ \\
\hline & 77.80 & 0.01 & 77.70 & 1.55 & *103.46 & 4 & 87 & 122 & 78.95 & 1.58 & $* 9.58$ & 1 & 6 & 12 & $3 / 22$ \\
\hline & 58.84 & 0.46 & 58.22 & 1.16 & $* 115.13$ & 18 & 142 & 53 & 65.79 & 1.32 & 4.53 & 2 & 9 & 8 & 23 \\
\hline & 55.17 & 0.64 & 54.46 & 1.09 & *169.89 & 17 & 160 & 36 & 63.16 & 1.26 & 5.16 & 2 & 10 & 7 & 24 \\
\hline & 77.80 & 0.01 & 77.70 & 1.55 & $* 102.20$ & 5 & 85 & 123 & 78.95 & 1.58 & $* 9.58$ & 1 & 6 & 12 & 25 \\
\hline & 46.98 & 1.36 & 46.01 & 0.92 & $* 61.38$ & 53 & 124 & 36 & 57.89 & 1.16 & 1.37 & 4 & 8 & 7 & 26 \\
\hline & 58.84 & 0.46 & 58.22 & 1.16 & *115.13 & 18 & 142 & 53 & 65.79 & 1.32 & 4.53 & 2 & 9 & 8 & 27 \\
\hline
\end{tabular}

Shown in table (5) search sample consensus on phrases numbers $(15,17,18,19$, and 26) between low approval rates (34.70:46.98\%) Non-commissioned study experience homes sports projects, not to develop benchmarks and indicators for the implementation of projects in the context of sustainable development, scenarios for not investing in sport and linked to national product, ack of coordination and cooperation between the Ministry of youth and sports and sports institutions.

Ahmed Abdel Hamid indicates zerdk, Mohammad Bassiouni (2011), Amal Mohammed Ibrahim Babiker (2011), Mr Ahmed Haj Issa (2013) to the importance of economic feasibility studies with quantitative method on the quality of the proposed project. (2:20) $(4: 38),(29: 18)$

While respondents had divergent views about the phrases numbers $(20,21)$ where she came by the approval of the Ministry of youth and sports $(52.63,68.42 \%)$, youth and sports modiriat approval $(29.34,37.56 \%)$ Not to put an outline to assess risks and reduce the negative consequences and achieve positive effects of sports institutions, as well as testing opportunities and potentials that work on sustainable alfo'aed of sports projects. Nice study recommends abdelli (2012) preselection process scheme should be built featuring various risks facing the Organization and practical stages. (17:168).

The researcher believes that risk management has an important role in ensuring the survival and sustainability of sporting institutions under accelerated and environmental conditions which achieve sustainability of those institutions. Search sample agreed on terms of numbers $(16,22,23,24,25$, and 27) ratios ranged between $(55.17: 77.80 \%)$ To take the necessary means to promote a positive legacy for the Olympics host city, to become the State Organization medias international media as well as sports tourism development with security, stability, development and upgrading to international and global levels

Indicate Both of Hassan Atteia al Shafi'i (2001) (13), Nadia Lutfi Abdel Fattah Mouawad (2008) (24) to organize and host the Olympics has become a major economic source return to the host State all the goodness and prosperity (13:113). The researcher believes that the Olympics and sports leagues big role in revealing how the State economically and socially and culturally and technologically realizing her payoff in the sustainable development of society as a whole 
Table (6)

Third axis statements approval rate social dimensions $(\mathrm{n}=232)$

\begin{tabular}{|c|c|c|c|c|c|c|c|c|c|c|c|c|c|c|c|}
\hline \multicolumn{2}{|c|}{$\begin{array}{l}\text { Research group at all } \\
n=232\end{array}$} & \multirow{2}{*}{$\begin{array}{l}\text { q2 for the } \\
\text { two classes }\end{array}$} & \multicolumn{6}{|c|}{ Second class : Youth directorates $n=213$} & \multicolumn{6}{|c|}{ First class:Ministry of YOUTH:N=19 } & \multirow{2}{*}{$\begin{array}{c}\text { Phrase } \\
\text { N }\end{array}$} \\
\hline arrangement & $\begin{array}{l}\text { Approval } \\
\text { rate }\end{array}$ & & $\begin{array}{l}\text { Approval } \\
\text { rate }\end{array}$ & mean & q2 & NO & fairly & Yes & $\begin{array}{l}\text { Approval } \\
\text { rate }\end{array}$ & mean & q2 & NO & fairly & Yes & \\
\hline & & & & & & & & & & & & & & & 28 \\
\hline & 46.98 & 1.36 & 46.01 & 0.92 & *61.38 & 53 & 124 & 36 & 57.89 & 1.16 & 1.37 & 4 & 8 & 7 & $1 / 28$ \\
\hline & 75.00 & 0.01 & 74.88 & 1.50 & *79.13 & 18 & 71 & 124 & 76.32 & 1.53 & *8.32 & 2 & 5 & 12 & $2 / 28$ \\
\hline & 46.98 & 1.36 & 46.01 & 0.92 & *169.38 & 35 & 160 & 18 & 57.89 & 1.16 & 3.89 & 3 & 10 & 6 & $3 / 28$ \\
\hline & 54.74 & 0.72 & 53.99 & 1.08 & *61.38 & 36 & 124 & 53 & 63.16 & 1.26 & 2.63 & 3 & 8 & 8 & $4 / 28$ \\
\hline & 81.68 & 0.00 & 81.69 & 1.63 & *128.37 & 4 & 70 & 139 & 81.58 & 1.63 & *11.79 & 1 & 5 & 13 & $5 / 28$ \\
\hline & 61.85 & 0.39 & 61.27 & 1.23 & $* 165.30$ & 5 & 155 & 53 & 68.42 & 1.37 & *7.05 & 1 & 10 & 8 & $6 / 28$ \\
\hline & & & & & & & & & & & & & & & 29 \\
\hline & 70.04 & 0.11 & 69.72 & 1.39 & *98.37 & 5 & 119 & 89 & 73.68 & 1.47 & $* 7.05$ & 1 & 8 & 10 & $1 / 29$ \\
\hline & 71.34 & 0.05 & 71.13 & 1.42 & *63.89 & 17 & 89 & 107 & 73.68 & 1.47 & $* 6.42$ & 2 & 6 & 11 & $2 / 29$ \\
\hline & 58.84 & 0.46 & 58.22 & 1.16 & *115.13 & 18 & 142 & 53 & 65.79 & 1.32 & 4.53 & 2 & 9 & 8 & $3 / 29$ \\
\hline & & & & & & & & & & & & & & & 30 \\
\hline & 59.05 & 0.43 & 58.45 & 1.17 & $* 36.51$ & 35 & 107 & 71 & 65.79 & 1.32 & 2.95 & 3 & 7 & 9 & $1 / 30$ \\
\hline & 66.16 & 0.21 & 65.73 & 1.31 & $* 126.45$ & 4 & 138 & 71 & 71.05 & 1.42 & $* 6.74$ & 1 & 9 & 9 & $2 / 30$ \\
\hline & 51.08 & 0.96 & 50.23 & 1.00 & *241.89 & 17 & 178 & 18 & 60.53 & 1.21 & $* 6.42$ & 2 & 11 & 6 & $3 / 30$ \\
\hline & 66.59 & 0.17 & 66.20 & 1.32 & *134.11 & 2 & 140 & 71 & 71.05 & 1.42 & $* 6.74$ & 1 & 9 & 9 & $4 / 30$ \\
\hline & 58.62 & 0.49 & 57.98 & 1.16 & $* 236.65$ & 2 & 175 & 36 & 65.79 & 1.32 & $* 8.00$ & 1 & 11 & 7 & $5 / 30$ \\
\hline & & & & & & & & & & & & & & & 31 \\
\hline & 43.10 & 1.80 & 42.02 & 0.84 & $* 35.52$ & 70 & 107 & 36 & 55.26 & 1.11 & 0.42 & 5 & 7 & 7 & $1 / 31$ \\
\hline & 38.79 & 2.52 & 37.56 & 0.75 & *79.13 & 71 & 124 & 18 & 52.63 & 1.05 & 0.74 & 5 & 8 & 6 & $2 / 31$ \\
\hline & 55.17 & 0.64 & 54.46 & 1.09 & *169.89 & 17 & 160 & 36 & 63.16 & 1.26 & 5.16 & 2 & 10 & 7 & $3 / 31$ \\
\hline & 54.74 & 0.72 & 53.99 & 1.08 & $* 61.38$ & 36 & 124 & 53 & 63.16 & 1.26 & 2.63 & 3 & 8 & 8 & $4 / 31$ \\
\hline & 50.86 & 1.00 & 50.00 & 1.00 & $* 27.38$ & 53 & 107 & 53 & 60.53 & 1.21 & 1.37 & 4 & 7 & 8 & $5 / 31$ \\
\hline & 67.24 & 0.12 & 66.90 & 1.34 & *36.51 & 35 & 71 & 107 & 71.05 & 1.42 & 5.47 & 3 & 5 & 11 & 32 \\
\hline & 83.41 & 0.02 & 83.57 & 1.67 & *169.89 & 17 & 36 & 160 & 81.58 & 1.63 & $* 14.00$ & 2 & 3 & 14 & 33 \\
\hline & 77.16 & 0.02 & 77.00 & 1.54 & *97.89 & 6 & 86 & 121 & 78.95 & 1.58 & $* 9.58$ & 1 & 6 & 12 & 34 \\
\hline & 65.95 & 0.23 & 65.49 & 1.31 & $* 134.20$ & 3 & 141 & 69 & 71.05 & 1.42 & $* 6.74$ & 1 & 9 & 9 & 35 \\
\hline & 54.74 & 0.72 & 53.99 & 1.08 & *61.38 & 36 & 124 & 53 & 63.16 & 1.26 & 2.63 & 3 & 8 & 8 & 36 \\
\hline & 54.96 & 0.68 & 54.23 & 1.08 & $* 9.13$ & 53 & 89 & 71 & 63.16 & 1.26 & 2.00 & 4 & 6 & 9 & 37 \\
\hline & 63.15 & 0.25 & 62.68 & 1.25 & $* 27.38$ & 35 & 89 & 89 & 68.42 & 1.37 & 3.89 & 3 & 6 & 10 & 38 \\
\hline & 75.00 & 0.01 & 74.88 & 1.50 & *79.13 & 18 & 71 & 124 & 76.32 & 1.53 & $* 8.32$ & 2 & 5 & 12 & 39 \\
\hline
\end{tabular}

*q2 Significant among responses with 0,05=5,99

significant between the two classes $=3,84$

Illustrated by table (6) consensus on low search sample phrases numbers $(28 / 1,3 / 28,31 / 1,31 / 2)$ ranged between (38.79:46.98\%) Not sought Ministry of youth and sport to promote peace and security efforts through the Elimination of hotbeds of tension and eliminate their causes and sound means of dialogue and negotiation, not to devote efforts to ensure that the spirit of fair play and prevention of violence in sport, as well as not to interprete the vision of sustainable development
Invites United Nations system organizations (2009) including the bodies and organizations concerned with sport media and media and civil society in cooperation with United Nations Office for sport for development and peace. (3:38)

The results of a study of Isabella D Bunn (2012) (32) confirms that the institutions take into account to achieve success in ways that respect ethical values and the natural environment 
Respondents agreed by assent medium about phrases $(28 / 4,6 / 28,29,30,31 / 3,31 / 4,31,32,35,36,37,38)$ and consent between (50.86:66.59\%) Not sought Ministry of youth and sports enough to promote peace efforts, not to encourage dialogue between different civilizations, poor cooperation with the authorities and public and private organizations, lack of interest in studying reasons for the reluctance of some community groups about exercise, not to the Ministry of youth and sports has sought to interprete the vision of sustainable development into reality, not paying attention to the conclusion the impact of violence and crime on societal degradation

he results of the study of Eid Mohammed Kanaan (2010) (8), studying both Catherine Benoît \& Niederman Vickery Gina (2010) (31), Faisal Abdul Aziz bin ajlan (2011) (9) indicate that there are religious constraints and obstacles related to sports potential, limit the participation of students in sports activities.

The researcher agrees with the recommendation of the study both of Amal Mehdi Kazhim, Wedad Youssef Mohammed (2012) (3) that the need for intensive media campaigns media to promote positive attitudes towards sports activities.

While there was consensus among respondents about phrases $(28 / 1,29 / 1,29 / 2,33,34,39)$ approval rates ranged between $(70.4: 83.41 \%)$ To devote efforts to ensure that the spirit of fair play, encourage the coordination and organization of activities and sports competitions, wetshgsa support the participation of women in sports activities, enable the disabled and enhance their role in community participation.

While there was consensus among respondents about phrases $(28 / 1,29 / 1,29 / 2,33,34,39)$ approval rates ranged between $(70.4: 83.41 \%)$ To devote efforts to ensure that the spirit of fair play, encourage the coordination and organization of activities and sports competitions, wetshgsa support the participation of women in sports activities, enable the disabled and enhance their role in community participation

Indicates Hassan Ahmed Shafi'i (2012), study Fataimh Bohani (2012) (10) to the inability of some sports organizations to broaden the base of sports and the scarcity of games for disabled and ladies. (15:22)

The researcher believes that sports activities on a regular basis is essential for the growth of the individual physical and mental, psychological and social, as it helps reduce crime
County youth and sports ministry deas not work to achieve the environmental dimension of sustainable development through the inclusion of human rights in a balanced environment

Not to encourage all stakeholders from Governments and non-governmental organizations to activate the tripartite system, sports, tourism, environment

Not depending on experience centers to study sports projects and its effect on the Egyptian economy

Lack of coordination and cooperation between the Ministry of youth and sports and various sports institutions to activate its role in increasing the nation's economic output

There are attempts to enable the disabled and enhance their role in community participation.

Recommendations: those entrusted with
recommendations

\section{Ministry \&directorates of youth and sports in the Arab} Republic of Egypt

Confirm the inclusion of sport as a means of achieving sustainable development within the scheme of "Egypt's Vision 2030" by forming a Committee membership comprises Minister of youth and sports and efficient components and expertise

Insert the right balanced environment and sustainable development within the fundamental rights

Legislation to determine the maximum concentration levels of pollutants inside the sports facilities

Give attension to Sports tourism development through tournaments in tourist places

Promoting the integration of people with disabilities in various sports activities

Need to make more effort to inform the public on the importance of combating hooliganism and racism...

\section{Rreferances}

\section{Frist: Arabic referances:}

1- Abdul Aziz Mukhaimar Abdel Hady (2007): "Toward a constitutional amendment in the field of environmental protection in the Egyptian legal system", Legal and Economic conference XI, Faculty of Law, University of Mansoura

\section{Recommendations}


2- Ahmed Abdel-Hamid Zrdq, Mohammed Saeed Bassiouni (2011): "Principles of economic feasibility studies", Faculty of Commerce, Banha University.

3- Amal Mahdi Kazim, Dad Mohammad Yousuf (2012): "Reluctance of female students for the sport of swimming", The Professor magazine, Vol. 203, University of Diyala, Iraq.

4- Amal Mohammed Ibrahim Babiker, Tayeb Haj Ibrahim, Abdel Moneim Ibrahim Tawfiq Hepa (2011): "Marketing and investment in the field of sports", Faculty of Physical Education and Sports, Sudan University of Science and Technology.

5- Ammar Amari (2008), "the problem of sustainable development and its dimensions", International Conference on Sustainable Development, University of Setif, Algeria

6- Asia Qascime (2012): "Sustainable development between the right to exploit natural resources and the responsibility to protect the environment", University in Beja, Tunisia

7- Bader Mohammad Alwan (2012): "Effectiveness of internal control in government departments based on auditing standards and their impact on sustainable development", Journal of Internation Financial Management and Accounting, Philadelphia University

8- Eid Mohammed Kanaan (2010): "Obstacles to the participation of students north of Jordan in sports activities", Damascus University Journal, Vol. 26, Syria.

9- Faisal bin Abdul Aziz bin Ajlan Ajlan (2011): "Sports clubs, programs and their role in protecting young people from distractions", Master Thesis, Naif Arab University for Security Sciences (NAUSS).

10- Fatima Pohany (2012): "Sports media in Algeria and its role in sustainable development", 1st Annual Arab Media Forum, Saudi Journalist Club, UK

11- First Scientific International Forum (2012): "Sports practice among tourism and environmental system", Institute of Science and Technology of Physical and Sporting Activities (ISTAPS), Bouira University, Algeria

12- Hamima Ibrahim Hashish, Samah Ahmed Salah, Donia Mohammed Adel (2010): "Sustainable development of investment projects in the application of sports institutions requirements", International Conference of the Supreme Council of Universities-Egypt

13- Hassan Ahmed El Shafei (2001): "Physical Education and the phenomenon of globalization era", Art radiation Library and press, 1st. Edition, Alexandria, Egypt
14- Hassan Shafie (2012): "Sustainable development and environmental accounting audit of Physical Education and Sports", Dar al-Wafaa for printing and publishing, 1st. Edition, Alexandria, Egypt

15- Hassan Shafie, Mustafa Zankalouni, Rehab Amin (2009): "Environmental auditing to achieve the goals of sustainable development in the sports institutions", Faculty of Physical Education Journal, Tanta University.

16- Khalid Mustafa Qasim (2007): "Sustainable Development in the light of globalization", Arab League, Cairo

17- Latifa Abdali (2012): "The role and place of risk management in the economic institution", Master Thesis, University of Abu Bakr, Algeria

18- Library and press, Alexandria, Egypt

19- Mohammed Abbas Badawi (2011): "Models proposed for measuring environmental performance to assess the contributions of enterprises in the field of sustainable development", Journal of the Faculty of Commerce, Alexandria University.

20- Mohammed Abu al-Qasim Muhammad (2005): "Environmental Management Systems (EMS)", Assiut Journal of Environmental Studies, Faculty of Engineering, Twenty-ninth issue for July.

21- Mohammed Salah al-Sheikh (2002): "The economic and financial effects of the pollution of the environment and means of protection against", Art radiation

22- Mtanios Makhoul, Adnan Ghanem (2009): "EMS and its role in sustainable development", the Faculty of Economics, University of Damascus.

23- Murad Nasser (2010): "Sustainable development and its challenges in Algeria, Faculty of Economic Sciences, Journal of communication, No. 26.

24- Nadia Lutfi Abdel Fattah Mouawad (2008): "The organization of the Olympic and sports tournaments and their economical impact on the host country", Master Thesis, Faculty of Physical Education for Girls Alexandria University.

25- Najat Abdullah Elwaly (2012): "Sustainable development and its importance in the Arab world", Scientific Journal of Economic and Commerce, Ain Shams University, Issue.1.

26- Omar Nasrallah Qeshta, Rehab Ali Amin (2009): "Accounting for environmental costs for investment projects for sustainable development in the sports institutions", Scientific Journal of Physical Education and 
Sports, Faculty of Physical Education, Mansoura University, Vol. 12 for March, Egypt

27- Osman Mohamed Ghoneim, Magda Abu Zant (2010): "Sustainable development philosophy and methods of planning", Dar Safa, Amman.

28- Salah Abbas (2010): "Sustainable Development in the Arab World", University's Youth Foundation, Alexandria, Egypt

29- Syed Ahmed Haj Issa (2013): "Sports sponsorship to improve the economic picture of the enterprise and professional sports organization industry", Nashiri Magazine, Fifth year, Tenth Issue, March

30- Talaat Moustafa Serougy (2009): "Social development of modernity to globalization", University Office, Cairo.

\section{Second: Foreign references}

31- Catherine Benoît \& Gina Vickery-Niederman (2011): Social Sustainability Assessment Literature Review, the Sustainability Consortium, Arizona State University.

32- Isabella D Bunn (2012): The Right to Development and International Economic Law, Cambridge Journal of International and Comparative Law, Volume 2(2)

33- Monika Freyman (2012): An Exploration of Sustainability and its Application to Corporate Reporting,
Initiative for Responsible Investment, Harvard University, United States.

34- OECD, Environmental Outlook to 2050, the Consequences of Inaction, March 2012

35- T. Hayward, Constitutional environmental rights, Oxford university press, 2005,

\section{Second: Internet}

36-

http://www.youm7.com/story/2016/2/29/2030/2608139

37- http://www.maannews.net/Content.aspx $? i d=473139$

38-

https://www1.umn.edu/humanrts/arabic/Health/Health31.p df

39- http://www.shathaaya.com

40- www.arch.hku.hk/research/ BEER/sustain .com by .Sam C M Hui. 2002

41- http://www.masralarabia.com/sports

42- www.emss.gov.eg/news_details.php?ID=24818 15 $13 / 2015$

43-

http:/greensportsalliance.org/wpcontent/uploads/2015/07/ SBJ_Sports-Sustainability-In-Depth_6.29.15.pdf 